\title{
Why some Countries are more Resilient in South Asia to Confront COVID-19 Pandemic and Recovery?
}

\author{
M Aminul Islam¹, Anika L. Islam², Shaika L. Islam³ \& Shamsun N. Ahmed ${ }^{4}$ \\ ${ }^{I}$ Senior Adviser, UNDP Bangladesh and former Director, Climate Change Program, Global Health Institute at \\ North South University, aminul.m@gmail.com \\ ${ }^{2}$ Ph.D. in Energy and Environmental Economics from Washington State University, anika.labiba@ gmail.com \\ ${ }^{3}$ Pursuing Ph.D. in Public Administration and Policy at Arizona State University, shaika.islam@ gmail.com \\ ${ }^{4}$ Professor of Economics, University of Dhaka, Bangladesh, shamsun.ahmed@gmail.com
}




\title{
WHY SOME COUNTRIES ARE MORE RESILIENT IN SOUTH ASIA TO CONFRONT COVID-19 PANDEMIC AND RECOVERY?
}

\begin{abstract}
This study explores the regional pattern of association between health risk exposure and resilience outcome in South Asian countries with the outbreak of Covid-19 pandemic. This exercise unveils the elements of resilience that contribute to get prepared in confronting COVID-19 risk in South Asia, using secondary information and knowledge from the Governments, WHO, UNDP Human Development Index (HDI), European Commission's COVID-19 Risk Index and the World Bank's Air Connectivity Index. Methodology and scope of the paper differs from previous contributions from a holistic policy point of view, since human development, geo-demographic vulnerability, government effectiveness and socio-economic outcome variables are considered in context to the public health condition and epidemic risk at the national level. Based on statistical evidences, South Asian countries fall into three categories (i) high resilient with low pandemic impact (Maldives, Bhutan and Sri Lanka), (ii) Medium resilient having high impact (India and Bangladesh) and (iii) Low resilient but high impact (Pakistan, Afghanistan and Nepal). Beyond resilience, this study also flags geo-demographic issues such as population density, geographical isolation either being island or landlocked mountainous countries and air travel connectivity as an influencing or barrier factors in spreading of epidemic disease. This paper serves the purpose of designing risk informed effective policy responses to constrain negative effects of future pandemic and similar infectious diseases and sensitize countries to get prepared for "build back better" as well.
\end{abstract}

Keywords: Resilience, epidemic risk, human development, risk informed policy \& planning

\section{Introduction}

South Asia (SA) experiences disproportionate health risks with the outbreak of the deadly surge of COVID-19, affecting almost all aspects of social, economic, public health and governance effectiveness. This paper focuses on epidemic vulnerability and risk in South Asian countries (Afghanistan, Bangladesh, Bhutan, India, Maldives, Nepal, Pakistan and Sri Lanka) from resilience context. Resilience is a spontaneous concept, but one without a generally agreed definition. We envisage it as an attribute of immunity in general sense. The region faces the challenges of the largest share of the "new poor" and high health costs, low internet connectivity and vulnerable industries. SA is the home to almost 2 billion people, collectively represent 25 percent of the global population, and now accounts for half of all new, known infections spirally growing globally (UNICEF 2021). South Asian countries were less fatal at the beginning but the situation changed since April 2021 with the evolving mutations. Initial study inference nullified as demographic advantage of bigger youth age group with stronger immunity, tropical warm climate and mass-scale vaccination for the protection against tuberculosis that creates a strong immune response against Covid-19 virus did not work as expected in the long run. Tradition of life and livelihood style and development dynamics in South Asia will never be the same after the COVID-19 pandemic, calls for a transformational change to get recovered with a mission of build back better. This situation has unveiled the status of the overall strength, capacity, weakness, opportunity and geographical privilege of a nation to capitalize towards meeting this uphill challenge to protect the lives and livelihoods of their citizens.

South Asian countries were less fatal in 2020 that prompted to speculate that tropical countries will fare better than temperate countries, potentially reflecting factors such as climate, exposure to malaria, or even high tuberculosis and pneumonia vaccination rates. Contemporary demographic structure in South Asia is another factor that exhibits good signs being predominantly younger age with better immune strength while high density susceptible to quick spreading of disease. As the number of COVID-related deaths disproportionately affects older people, South Asian countries may have a unique advantage (Zhang et al., 2020). India, Pakistan and Bangladesh are among the youngest countries in the world, with 5-8 percent of their populations aged over 60 and 2-3 percent aged over 70. This compares with Italy's age distribution of about 26 percent aged over 60 of which around 85- 
90 percent faced Covid-19 deaths fatality risk (Brewster 2020). However, this scenario has been changed in 2021 with the outbreak of muted "Delta variant" which is fast spreader and affecting all age groups.

Pandemic makes matter worse as established mechanisms for reducing poverty are not working and may be unavailable for months. In some of the South Asian economies it is a difficult choice for the decision makers how to maintain life and livelihood in pandemic situation. Schools in many countries are closed for more than year are already vulnerable to dropping out of school may not go back or join the poor class. School-lunch programs are the main source of support to provide food and nutrition for children and attend to their health needs are compromised. This situation is further deteriorating case particularly for girls who are also pushed to go for early marriage in South Asia.

Question of big data management linked to household level basic needs demand and supply chain is another dimension of planning better public health. In this process, effective local government institutions play a critical role to meet the local level citizen's need with back-up support through social safety net programme. Policy and planning must reflect equity, justice and right base approach in the governance system that ensures effective engagement of people in emergency response and to follow health rules. This is an alarming concern as the recent Oxfam study reveals the fact that globally 12,000 people per day could die from Covid-19 linked hunger by the end of year, potentially more than the disease (OXFAM 2020). This could be a successful case of Covid-19 pandemic response strategy for densely populated country if household level dynamics are captured in data management system. Apex health management body in each country carries out these activities in collaboration with state, local, and territorial health departments; public health, commercial, and clinical laboratories; vital statistics offices; health care providers; emergency departments; and academic and private sector partners. A broad-based common platform of stakeholders can share their recommendations to take emergency decisions based on data as and when require for targeting beneficiaries and their demands. This data driven management with basic needs responsive arrangement for each citizen by age group should be part of risk informed planning process (Sarkar et al., 2020). With this background in view, this paper attempts to explore the relationship that closer the connectivity between citizen and public service entities better the outcome in pandemic management.

This paper is different in approach from previous studies so far undertaken from a risk informed policy decision point of view, since many of the geo-demographic vulnerability and socio-economic outcome variables are compared to understand the related trend with the public health condition and epidemic risk. Situation analysis gives an insight about the underlying associations between the health science and social sciences from the perspective of resilience and human development (Guhathakurata, et al., 2021, Giridhara 2021, Mangi and Devnath 2020). Haldane et al., (2021) emphasized that health is more than healthcare and that a whole-ofgovernment approach to health and well-being is needed to create healthy populations able to collectively prevent and respond to crises, leaving no one behind. Perrings (1998) offered a more open definition of resilience: "in its broadest sense, resilience as a measure of the ability of a system to withstand stresses and shocks" (Olsson et al., 2015). On the other hand, Human Development Index (HDI) of United Nations Development Programme uses three key dimensions (i) a long and healthy life - measured by life expectancy, (ii) access to educational system - measured by expected years of schooling of children at school-entry age and mean years of schooling of the adult population and (iii) a decent standard of living (UNDP 2020) - measured by Gross National Income (GNI) per capita adjusted for the price level of the country (Roser 2014). This paper brings both resilience and risk face to face.

The World Bank study (World Bank 2021) shows that the pandemic's effects have been most uneven in countries where pre-existing inequalities were greatest - where access to basic lifeline opportunities such as education, clean water, and electricity are largely determined by circumstances such as location, parental background, and household wealth. This pandemic outbreak has unveiled pockets of epidemic hotspots characterized by inadequate health facilities and socio-economic deprivation within each country. South Asian countries account for 33.4 percent of the world's low-income population, of which almost half live in India (21.2 percent) and Bangladesh (18.5 percent) although these countries are categorized under Medium Human Development category (World Bank 2021). In these countries, the pandemic risks further reinforcing inequality of opportunity unless rapid action is taken. The crisis provides a reform opportunity to address the barriers in access to health care facilities, job creation, education and other basic needs services, financial incentives and others, and that have made small 
countries with comparatively low population to quickly adopt smart solution as well as follow-up policy and investment measures.

This paper is presenting a collection of data from secondary sources to support risk informed policy decisionmaking to address Covid-19 pandemic and emerging multi-dimensional vulnerable situation. An attempt is made to support prioritization of preparedness and early response actions for the primary impacts of the pandemic, and identify South Asian countries where secondary impacts are likely to have the most critical humanitarian consequences. The quality of policy choice and implementation are associated with sustainable development leveraging economic efficiency, sectoral performance, and governance effectiveness, peoples' level of awareness and living standard.

\section{Literature Review}

Sagan et al., (2020) reviewed the literature on strategies for strengthening health system resilience and for responding to system shocks, as well as emerging evidence from national responses to the COVID-19 pandemic. They mapped those strategies to the key health system functions include governance, financing, resources and service delivery. The pandemic has exposed the limitations of many health systems, including some that have been previously classified as high performing and resilient (E1 Bcheraoui, 2020). Disproportionate health risk and crisis management vary over country and regime in South Asia and is difficult to compare from socio-economic and vulnerability context. In general, existing health infrastructure is usually deficient (Jayathilake et al. 2021). Level of resilience is one of the determining factors to combat epidemic vulnerability as a case hardly we noticed in literature review. UNISDR (2009) refers resilience to multiple aspects ranging from absorbing and recovering from, to resisting, the effects of a hazard such as virus attack, as well as preserving and restoring "essential basic structures and functions".

Guhathakurata et al., (2020) identified crucial factors responsible for low death rates in South Asian countries because of (i) Bacillus Calmette-Guerin (BCG) vaccine given in past to protect from tuberculosis creates strong immunity against Covid 19, (ii) high average temperature (21 to 300 Celsius), (iii) average age of population mostly younger in SA are stronger in immunity and (iv) herd immunity as people in SA are more experienced to high exposure to infectious diseases. One of the studies reported that the lower mortality rate in South Asian countries may not be sustainable over the long term. First, more than half of deaths occur in people with noncommunicable diseases. The spread of infection among people with comorbidities over the long term may increase mortality (Deepak, 2020). Study of Coccia (2020) explains the geo-environmental determinants of the accelerated diffusion of COVID-19 that is generating a high level of deaths associated with high levels of air pollution. This study also suggests a strategy to cope with future epidemic threats similar to COVID-19 having an accelerated viral infectivity in society. Same study notes that the accelerate and vast diffusion of COVID-19 in North Italy has a high association with air pollution of cities measured with days exceeding the limits set for PM10 (particulate matter $10 \mu \mathrm{m}$ or less in diameter) or ozone (Coccia 2020).

The lower mortality rate in South Asian countries may not be sustainable over the long term. First, more than half of deaths occur in people with non-communicable diseases. The spread of infection among people with comorbidities over the long term may increase mortality. A systematic literature review focusing on South Asian populations found that the mortality rate was higher in those with COVID-19 who also had diabetes. This is another reason why the reported low mortality rate can only be an exaggerated way to show that the pandemic response is better (Deepak, 2020).

Literatures marked that South Asian countries, mostly with large population were experiencing (March-June 2020) ineffective in lockdowns program to arrest the exponential growth of Covid 19 cases in Afghanistan, Pakistan, Nepal, India and Bangladesh. However, Bhutan, Maldives and Sri Lanka have been successfully limiting the spread of the disease (Sarkar et al. 2020). However, geographical isolation and population density issues are overlooked in explaining such case. South Asian countries are now easing lockdowns despite rising case numbers (Mondeaux, 2020). Healthcare facilities and hospitals are stretched due to the increase in the number of cases (Mangi and Devnath, 2020). It has been reported that testing levels in Pakistan and Bangladesh have fallen dramatically (Menon, 2020). Bangladesh did not act quickly during the early stages of the pandemic, which is 
thought to be one of the reasons why case numbers are now soaring. In addition, early interventions were not implemented very strictly (Mondeaux, 2020).

\section{COVID-19 Vulnerability and Risks Variation over countries in South Asia}

A number of studies [Shrestha et al. (2020), Howlader \& Khan (2020), Shah et al., (2020), Lancet (2020). and, Nafees \& Khan, (2020) reveal the fact that Bangladesh, India, Nepal, Pakistan and Afghanistan had limited preparation in planning in combating pandemic COVID-19, whereas Maldives, Bhutan, and Sri Lanka were comparatively well-prepared baseline status and planned attribute as found in pre-pandemic historical records. Report shows weak foundation of health infrastructure as evident from the 2015 Human Development Report of UNDP that indicates five of eight South Asian nations (India, Nepal, Bangladesh, Pakistan, and Afghanistan) having higher mortality rates among under 5 years and adults, greater prevalence of child malnutrition, higher mortality rates from tuberculosis, and lower life expectancy at 60 years compared with the global average (Sengupta et al., 2018). Pandemic preparedness and response to COVID-19 in South Asian countries is another study undertaken by Giridhara (2021) reached to a conclusion that the COVID-19 pandemic has provided a window for introspection, scaling up preparedness for future pandemics, and improving the health of the population overall.

\section{Geo-demographic Factors Influencing spread of Covid-19}

The countries with high population density in the SA region (Streatfield and Karar 2008) experiencing the chance of fast community transmission. Traditional cultural, religious and political events of big social gatherings and customs might be the core factor for community transmission in SA countries (Sultana, 2020). COVID-19 can be rapidly transmitted from person-to-person that makes this pandemic quite challenging to control. Islam et al., (2021) found that the spatial and temporal pattern of the COVID-19 varies across the region, which recommends customized country-specific prioritized policies identifying the real hotspot of infection and applying strict restriction of movement within hotspot areas. However, these studies overlooked the geographical factors and propensity of people's mobility as an issue of virus transmission.

The Worldometer - a real time world statistics provider (https://www.worldometers.info/) and WHO recorded from the onset of the outbreak up to 15 May, 2020 (Islam et al., 2021) showing higher in number of per day affected cases with the highest record in India followed by Pakistan and Bangladesh. While comparing with the same data source after an year for an example of data recorded on 15 July 2021, the highest cases of fatality rate were recorded in India, Bangladesh, Pakistan and Nepal among SA countries, whereas in both timeline for Bhutan, Maldives and Sri Lanka had the minimum death record due to COVID-19 so far (Islam et al., 2021).

\section{Air Connectivity and Covid-19 Prevalence}

Air connectivity index is grounded in network analysis methods, and is based on a gravity-like model that is familiar from the international trade and regional science literatures (World Bank 2011). Arvis and Shephard (2011) applied this connectivity index as a policy tool, rather than simply a means of describing network properties, as used in the applied mathematics literature. They also focus on the country as the level of analysisagain, this is important from a policy point of view, since many of the economic outcome variables that we would expect to be correlated with air connectivity are measured at the national, not airport, level. 
Table 1: Air Connectivity Index (2007) Source: Retrieved from Web at http://econ.worldbank. org. (Ref: JeanFrançois et al. 2011)

\begin{tabular}{lll}
\hline & ACI (\%) & Rank \\
\hline Afghanistan & 3.08 & 115 \\
\hline Bangladesh & 2.79 & 121 \\
\hline Bhutan & 2.74 & 123 \\
\hline India & 3.82 & 88 \\
\hline Maldives & 1.66 & 175 \\
\hline Nepal & 2.86 & 119 \\
\hline Pakistan & 3.23 & 111 \\
\hline Sri Lanka & 2.02 & 144
\end{tabular}

Government of South Asian Countries issued time to time location specific lockdown declaration to control carrier of virus and to cope with the increasing number of COVID-19 cases since March 2020. This has implications on spread and death cases and peoples' movement as well as energy consumption in South Asian countries. However, as the lockdown relaxed, people and transport movement started to recover. In this study, we investigated background of country wise COVID-19 variations.

\section{Implications of Informal Economy and Lock-down to Contain Covid-19}

Sarkar et al., (2020) based on the data from March 21 to June 26, 2020, find that lockdown program along with other control measures were not as effective to arrest the exponential growth of fortnightly COVID-19 cases in Afghanistan, Bangladesh, India, Nepal and Pakistan. However, Bhutan, Maldives and Sri Lanka have been successfully limiting the spread of the disease due to manageable population closely linked to the effective local governance. Countries with large share of the informal economy means a higher cost of the lockdown and subsequent social distancing on businesses, and food production and distribution are more easily disrupted because of movement restrictions, threatening household living standards. There is a realization that COVID-19 is a collective crisis and combating this requires a coordinated action, it has not been translated into a concrete program of action at the regional level. For Bangladesh, India, and Pakistan, the poorest third of the population relying on the informal economy lost 9 percent, 13 percent, and 16 percent of their incomes respectively. Losses for the informal population in the middle third of the distribution were almost similar at 11 percent, 7 percent, and 16 percent, whereas the richest 33 percent suffered less severe losses (World Bank Blogs, April 06, 2021).

\section{Materials and Methods}

Methodology and scope of the paper is designed in conformity to capture the research questions to unveil the elements of resilience that contribute to confront COVID-19 risk in South Asia, using secondary information and knowledge (European Union 2021). Data source used are governments of South Asian countries, WHO, UNDP Human Development Index (UNDP 2020) and the European Commission's eINFORM COVID-19 Risk Index (Poljansek et al., 2020) which is a composite index that identifies countries at risk from health and humanitarian impacts of COVID-19 and national response capacity. The INFORM COVID-19 Risk Index is primarily concerned with structural risk factors, i.e., those that existed before the outbreak. It can be used to support prioritization of preparedness and early response actions for the primary impacts of the pandemic and identify countries where secondary impacts are likely to have the most critical humanitarian consequences. The main scope of the INFORM COVID-19 Risk Index is global and regional risk-informed decision-making aide where comparable understanding of countries' risk is important. It cannot predict the impacts of the pandemic in individual countries. INFORM is working on developing other products that can help monitor changing risks as a result of the pandemic. 


\section{Results and Discussion}

European Union commissioned study (Poljansek et al., 2020) that generates Covid-19 vulnerability Index and risk based on number of components such as movement in percent by air transport, number of arrivals, point of entry access to cities, road density. Behavior is another component represented by the awareness measured by literacy rate, use of mobile phones and internet. Data on fatality rate and cumulative cases are shown in WHO portal (WHO Health Emergency Dashboard WHO (COVID-19) Homepage. Table 1 gives an understanding that except Bhutan and Maldives, all countries are comparatively vulnerable, whereas fatality rate (in percent) shows highest in Afghanistan and Pakistan and the lowest three countries are Maldives, Bhutan and Sri Lanka. India, Bangladesh and Nepal fall in the middle range of Covid fatality.

Table 2: Statistics related to Severity of Covid-19 in South Asian countries

\begin{tabular}{|c|c|c|c|c|c|}
\hline Country & $\begin{array}{l}\text { Covid-19 } \\
\text { Vulnerability }{ }^{1}\end{array}$ & $\begin{array}{l}\text { Covid- } \\
19 \text { Risk }\end{array}$ & $\begin{array}{l}\text { Cumulative } \\
\text { Cases/ Miln. } \\
\text { population }\end{array}$ & $\begin{array}{l}\text { Cumulative } \\
\text { Fatalities per } 1 \\
\text { Mil. Inhabitants }\end{array}$ & $\begin{array}{l}\text { Covid-19 Fatality rate } \\
\text { (percent) with at least } \\
100 \text { deaths }^{2}\end{array}$ \\
\hline Afghanistan & 3.5 & 6.8 & 999 & 36 & 4.1 \\
\hline Bangladesh & 3.9 & 5.2 & 1807 & 24 & 1.6 \\
\hline Bhutan & 2.7 & 4.2 & 203 & 0 & $0.0^{1}$ \\
\hline India & 4.5 & 4.6 & 2273 & 42 & 1.3 \\
\hline Maldives & 3.0 & 4.0 & 12768 & 49 & 0.3 \\
\hline Nepal & 3.4 & 5.1 & 1116 & 5 & 1.4 \\
\hline Pakistan & 3.4 & 5.3 & 1352 & 29 & 2.3 \\
\hline Sri Lanka & 5.5 & 4.3 & 138 & 1 & 1.2 \\
\hline
\end{tabular}

Source: Poljansek, K., Vernaccini, L. and Marin Ferrer, M., INFORM Covid-19 Risk Index, EUR 30240 EN, Publications Office of the European Union, Luxembourg, 2020

1 INFORM Annual Report 2021.pdf (europa.eu)

${ }^{2}$ Data retrieved from: https://portal.who.int/report and https://Covid19.who.int/table 
M Aminul Islam / Why some Countries are more Resilient in South Asia to Confront COVID-19 Pandemic and Recovery?

Table 3: Underlying factors for Resilience that assists in confronting Covid-19

\begin{tabular}{lllllllll}
\hline Country & $\begin{array}{l}\text { Life } \\
\text { Expect } \\
\text { ancy }\end{array}$ & $\begin{array}{l}\text { Govt. } \\
\text { Effectiv } \\
\text { eness } \\
\text { Index }\end{array}$ & $\begin{array}{l}\text { Adult } \\
\text { Literacy } \\
\text { Rate } \% \text { ) } \\
2008-18\end{array}$ & $\begin{array}{l}\text { GDP } \\
\text { per } \\
\text { Capita } \\
\text { in US\$ }\end{array}$ & $\begin{array}{l}\text { Health } \\
\text { Expenditure }_{\text {per capita }}^{2} \\
\text { US\$ PPP }\end{array}$ & $\begin{array}{l}\text { Human } \\
\text { Developmen } \\
\text { Index }^{3} \\
2018\end{array}$ & $\begin{array}{l}\text { Immunization } \\
\text { Coverage } \\
\text { BCG }^{\text {DTP3 }}\end{array}$ \\
\hline Afghanistan & 64.8 & 1.46 & 43.02 & 521 & 163 & 0.50 & 78 & 66 \\
\hline Bangladesh & 72.6 & 0.75 & 74.00 & 1698 & 91 & 0.61 & 99 & 98 \\
\hline Bhutan & 71.8 & 0.36 & 67.00 & 3360 & 293 & 0.62 & 92 & 97 \\
\hline India & 69.7 & 0.28 & 74.00 & 2016 & 241 & 0.65 & 92 & 91 \\
\hline Maldives & 78.9 & 0.49 & 98.00 & 10224 & 1629 & 0.72 & 99 & 99 \\
\hline Nepal & 70.8 & 0.90 & 68.00 & 1026 & 156 & 0.58 & 96 & 93 \\
\hline Pakistan & 67.3 & 0.63 & 59.00 & 1473 & 144 & 0.56 & 88 & 75 \\
\hline Sri Lanka & 77 & 0.24 & 92.00 & 4102 & 491 & 0.78 & 99 & 99 \\
\hline
\end{tabular}

Sources:

Poljansek, K., Vernaccini, L. and Marin Ferrer, M., INFORM Covid-19 Risk Index, EUR 30240 EN, Publications Office of the European Union, Luxembourg, 2020. Inter-Agency Standing Committee and the European Commission, INFORM report 2020: Shared evidence for managing crisis and disaster, EUR 30173 EN ISBN 978 92-76-17910-8, doi: 10.2760/953633, JRC120275

${ }^{1}$ Government effectiveness: Worldwide Governance Indicators World Bank http://info.worldbank.org/governance/wgi/

${ }^{2}$ WHO Current health expenditure per capita. Who Global Health Observatory Data Repository. http://apps.who.int/nha/database

${ }^{3}$ WHO Current health expenditure per capita. Who Global Health Observatory Data Repository. http://apps.who.int/nha/database

${ }^{4}$ Human Development Index UNDP HUMAN DEVELOPMENT REPORT http://hdr.undp.org/en/composite/HDI ${ }^{1}$ Coverage of DTP3 vaccine WHO, UNICEF https://unstats.un.org/sdgs/indicators/database/

Table 4: Pre-pandemic country wise degree of vulnerability and level of Health Risk presented at 0 -10 scale where $0=$ more reliable $10=$ Less reliable)

\begin{tabular}{llllllll}
\hline Country & $\begin{array}{l}\text { Vulner } \\
\text { ability } \\
(0-10)\end{array}$ & $\begin{array}{l}\text { Population } \\
\text { vulnerable to } \\
\text { Multi-dimensional } \\
\text { Poverty }^{(2014-19)}\end{array}$ & $\begin{array}{l}\text { Socio- } \\
\text { economic } \\
\text { Vulnerability } \\
0-10\end{array}$ & $\begin{array}{l}\text { Health } \\
\text { Conditi } \\
\text { on } \\
0-10\end{array}$ & $\begin{array}{l}\text { Food } \\
\text { Security } \\
0-10\end{array}$ & $\begin{array}{l}\text { Access to } \\
\text { Health } \\
\text { Care } \\
0-10\end{array}$ & $\begin{array}{l}\text { Epidemic } \\
\text { Inform } \\
\text { Risk } \\
0-10\end{array}$ \\
\hline $\begin{array}{l}\text { Afghanista } \\
\mathrm{n}\end{array}$ & 7.2 & 18.1 & 7.9 & 2.1 & 7.8 & 8.3 & 7.4 \\
\hline $\begin{array}{l}\text { Banglades } \\
\text { h }\end{array}$ & 6.6 & 18.2 & 5.3 & 2.0 & 4.3 & 5.2 & 6.1 \\
\hline Bhutan & 3.8 & 17.7 & 5.2 & 1.5 & 4.3 & 5.1 & 4.0 \\
\hline India & 5.4 & 19.3 & 4.6 & 2.2 & 4.4 & 5.5 & 5.1 \\
\hline Maldives & 2.7 & 4.8 & 2.6 & 0.3 & 3.1 & 3.2 & 3.2 \\
\hline Nepal & 5.1 & 22.4 & 5.9 & 2.3 & 2.7 & 6.0 & 6.0 \\
\hline Pakistan & 6.0 & 12.9 & 5.3 & 1.8 & 5.3 & 6.2 & 6.2 \\
\hline Sri Lanka & 4.5 & 14.3 & 2.6 & 0.4 & 3.0 & 4.1 & 4.8 \\
\hline
\end{tabular}

${ }^{1}$ Multidimensional Poverty Index UNDP Human Development Report http://hdr.undp.org/en/composite/MPI

${ }^{1}$ INFORM Annual Report 2021.pdf (europa.eu) 
South Asian countries have a wide range of variation in epidemic inform risk low in Maldives, Bhutan and Sri Lanka (3.2- 4.8) and the highest level experiences in Afghanistan (7.4). This regional pattern of health risk is corresponding to the status on access to health care situation where one can find that Maldives, Bhutan, Sri Lanka are in better position (ranging between 3.2 - 5.1) and worst case scenario in Afghanistan followed by Pakistan and Nepal (ranging between 6.0-8.3). It is evident from the World Bank study on comparison of health expenditure per capita among South Asian countries where Maldives, Bhutan and Sri Lanka are on the top performer (see following figure).

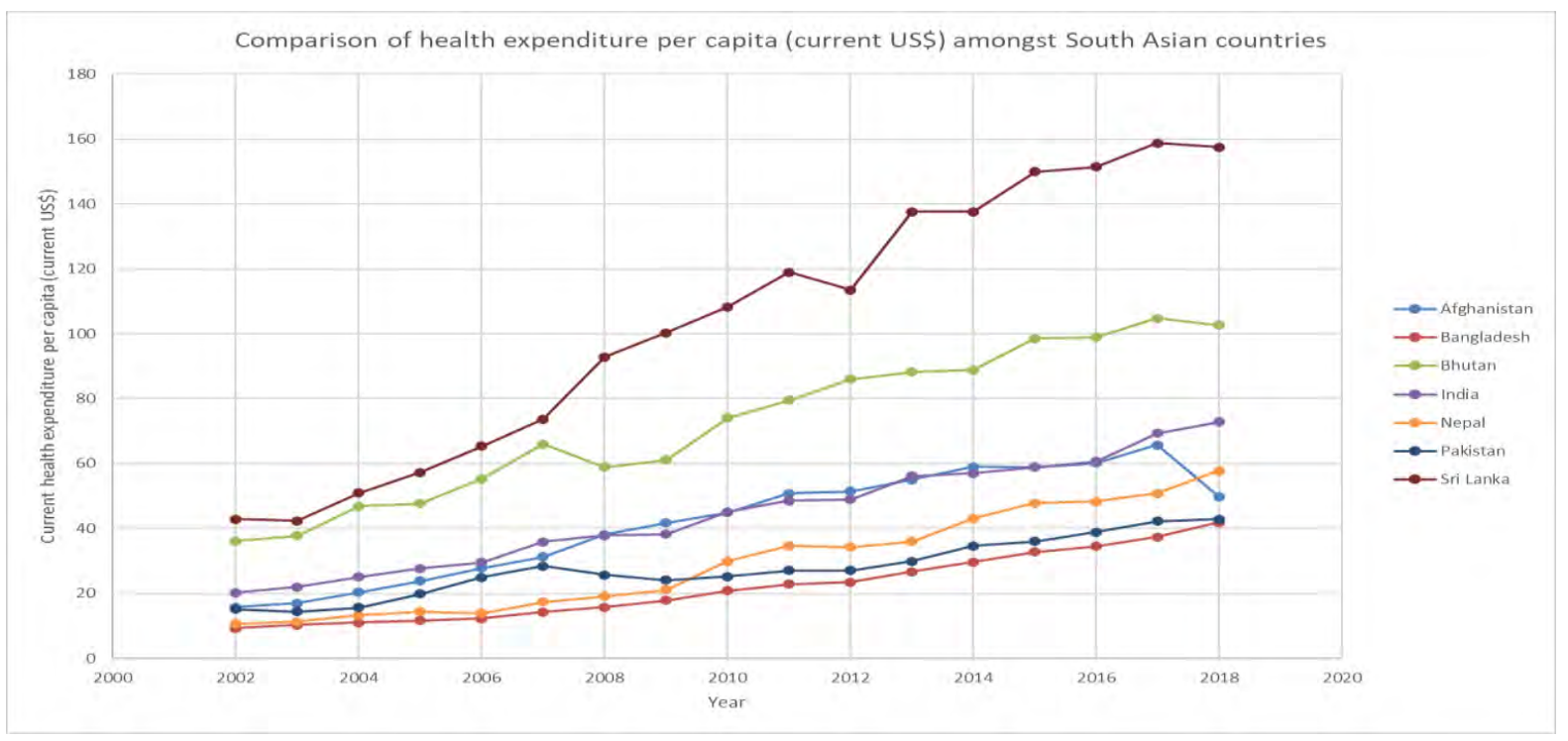

Figure 1: Comparison of health expenditure per capita (current US\$) amongst South Asian countries

Source: World Bank, Health: Health systems, World Health Organization Global Health Expenditure database

\section{Relation between Resilience and Covid-19 Vulnerability and Risk}

From the onset of the pandemic, policy analysts have been trying to understand how a country develops resilience and trying to know what constitutes a resilient response (Legido et al., 2020). Data used for comparative and situational analysis to get an understanding of resilience and epidemic risk relation are published sources from the governments of South Asian countries, WHO, UNDP Human Development Index and the European Commission's eINFORM COVID-19 Risk Index which is a composite index that identifies countries at risk from health and humanitarian impacts of COVID-19 and national response capacity. On the basis of the results of indicator data by country are grouped into 3 clusters (i) high, (ii) medium and (iii) low resilient countries; characterized by (i) low risk, (ii) moderate risk and (iii) high risk. This study identified three categories of South Asian countries experiencing Covid-19 impact and vulnerabilities: (i) Highly resilient and low impact of Covid19 countries are Bhutan, Maldives and Sri Lanka (ii) Medium Resilient but high impact of Covid-19 countries are India and Bangladesh and (iii) Low resilient but high impact of Covid-19 are Afghanistan, Pakistan and Nepal.

The Global Health Security Index scores on overall risk environment and national vulnerability to biological threats (highest possible score is 100) for South Asian countries were: 58.3for the Maldives, 56.9 for Bhutan, 56.7 for Sri Lanka, 54.4 for India, 38.7 for Pakistan, 44.7 for Nepal, 44 for Bangladesh, and 32.3 for Afghanistan (Giridhara et al. 2021). This finding explains that each country in the region had different preparedness levels to tackle a pandemic, with the Maldives, Bhutan and Sri Lanka being better ranked and score holders in reducing biological threats and Afghanistan and Pakistan being least prepared.

Our study identified the facts that pre-Covid steps of each country in South Asia regarding COVID-19 risk reduction and preparedness policy with lesser population density and smaller the size of country having higher per capita investment in health and socio-economic sectors created closer the connectivity between citizen and public service entities that makes a difference. Efficiency in big data management and effective local government 
institutions working at the citizen's level is instrumental to deliver better expected results in pandemic management. We also observed that smaller the country better the performance in delivering target benefits.

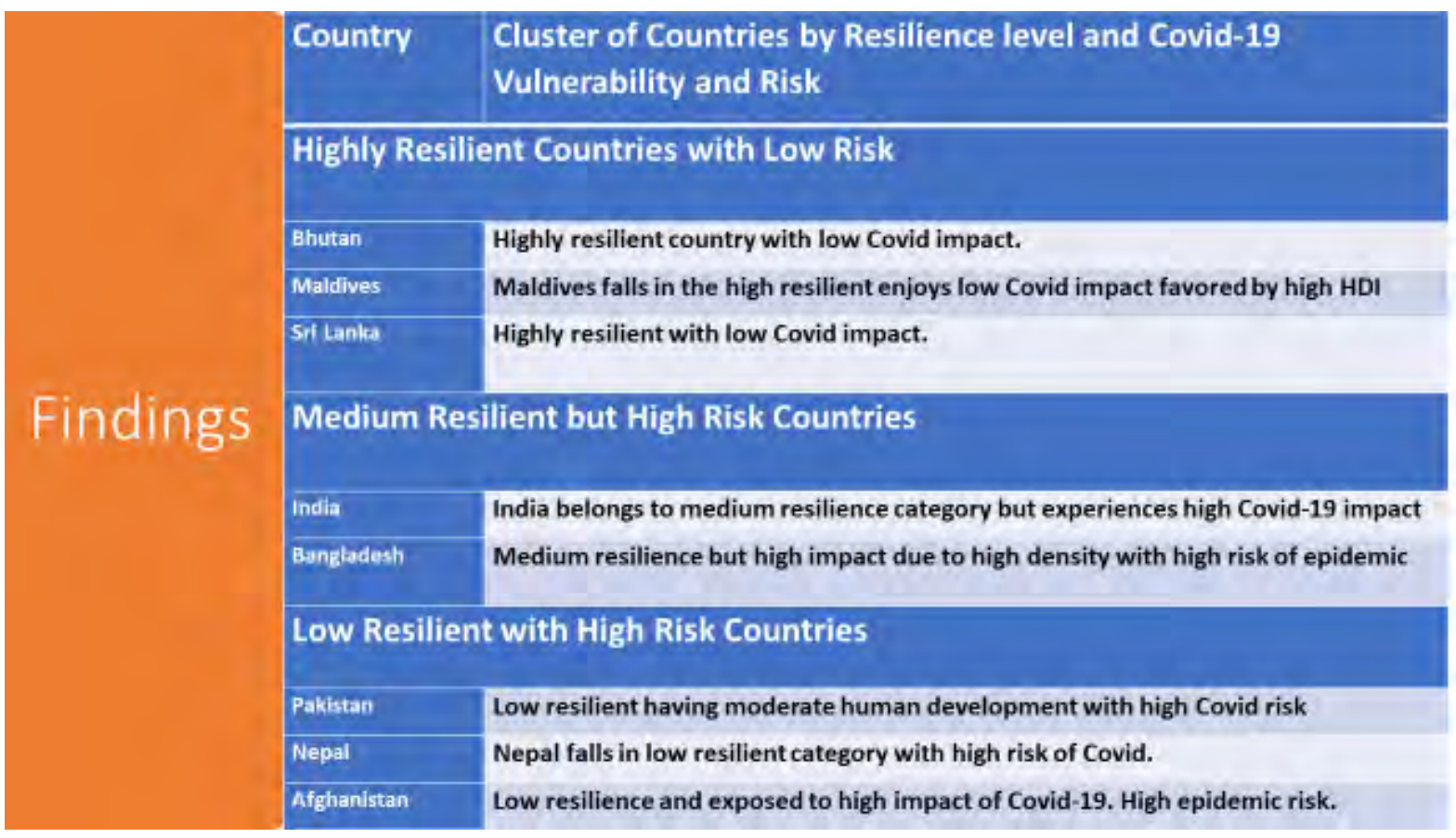

\section{Figure 2: Cluster of Countries by Resilience level and Covid-19 Vulnerability and Risk}

Source: Situation analysis of pre-Covid and during Covid data trend on socio-economic, geo-demographic, public health (proxy for resilience), and epidemic vulnerability \& risk in South Asian Countries.

While battling the COVID-19 crisis, there is a sense of urgency to cover up the policy, planning and investment gaps as exposed to get prepare for future pandemics. This requires strong leadership and great political will to allocate substantial resources to prepare for building resilience. Also, a strong regional plan and collaborative strategies for sustainable development engaging broad based stakeholders can enhance social protection to secure livelihoods as well as mitigate potential deaths among the poor and vulnerable (Giridhara 2021). This should be commenced by evaluating and analyzing the gaps of the current capacities and priorities at the human resource development, institutional and systemic level for pandemic preparedness, and planning and addressing them.

\section{Concluding Remarks}

South Asian countries generally had inadequate pandemic preparedness as the nations do not have effective governance to meet public health crisis, lacks robust national policy on comprehensive health security, plans, guidelines, or laws that account for the surveillance and control of diseases transmission a concern for public health in addition to the unregulated private sector without any role in the implementation of universal health coverage. Investment priority should focus heavily in building strong and resilient health systems with reasonable financial allocations and collaborate for emergency action and improve public health infrastructure and efficiency. Raising inclusive resilience level among the nations in South Asia is a priority concern towards achieving winwin goals of both socio-economic improvement and better public health.

There is a priority concern to consider risk informed policy and planning anchored on smart data systems for a transformational change and effective management of emergency and future epidemic. It is evident that smaller the country better the performance in delivering such resilience oriented benefits. The pandemic experience highlighted the importance of electronic surveillance of citizen level basic livelihood, food and disease for preparedness facts and figures to respond pandemic and planning crisis management while declaring lockdown or shut down at any hotspots. Resilience-led growth with digital risk informed data support in the region will not only bring significant economic returns but also help bridge existing divides in access to education and healthcare, financial incentives and public service delivery. 


\section{References}

Arvis, J. F., \& Shepherd, B. (2011). The air connectivity index: measuring integration in the global air transport network. World Bank Policy Research Working Paper, (5722).

Brewster, D. (2020). Why South Asia may come out of Covid-19 crisis better then many expect, The Interpreter, published by the Lowy Institute. Available at: https://www.lowyinstitute.org/the-interpreter/why-south-asiamay-come-out-covid-19-crisis-better-many-expect

Coccia, M. (2020). Factors determining the diffusion of COVID-19 and suggested strategy to prevent future accelerated viral infectivity similar to COVID. Science of the Total Environment, 729, 138474.

Deyshappriya, N. R. (2018). Examining poverty trends in South Asian countries: where is Sri Lanka among its South Asian counterparts? South Asia@LSE.

Deepak N. 2020. The COVID-19 paradox in South Asia. The Hindu, 24 April.

https://www.thehindu.com/opinion/lead/the-covid-19-paradox-in-south-asia/article31417806.ece

El Bcheraoui, C., Weishaar, H., Pozo-Martin, F., \& Hanefeld, J. (2020). Assessing COVID-19 through the lens of health systems' preparedness: time for a change. Globalization and Health, 16(1), 1-5.

European Union. (2021). Worldwide Data on Covid-19. Available at: https://www.ecdc.europa.eu/en/covid$\underline{19 / \text { data }}$

Gerard, F., Imbert, C., \& Orkin, K. (2020). Social protection response to the COVID-19 crisis: options for developing countries. Oxford Review of Economic Policy, 36(Supplement_1), S281-S296.

Giridhara R. B., Sonalini Khetrapal, Daisy A. John, R. Deepa, K.M. Venkat Narayan. (2021). Pandemic preparedness and response to COVID-19 in South Asian countries. Int J Infect Dis. 2021 Mar; 104: 169-174.

Guhathakurata, S., Saha, S., Kundu, S., Chakraborty, A., \& Banerjee, J. S. (2021). South Asian Countries are less fatal concerning COVID-19: a fact-finding procedure integrating machine learning \& multiple criteria decision-making (MCDM) technique. Journal of The Institution of Engineers (India): Series B, 1-15.

Haldane, V., De Foo, C., Abdalla, S. M., Jung, A. S., Tan, M., Wu, S., ... \& Legido-Quigley, H. (2021). Health systems resilience in managing the COVID-19 pandemic: lessons from 28 countries. Nature Medicine, 1-17.

Howlader, T., \& Khan, H. R. (2020). Battling the COVID-19 pandemic is Bangladesh prepared. Medrxiv, 1-20. Islam, A., Sayeed, M. A., Rahman, M. K., Ferdous, J., Shano, S., Choudhury, S. D., \& Hassan, M. M. (2021). Spatiotemporal patterns and trends of community transmission of the pandemic COVID-19 in South Asia: Bangladesh as a case study. Biosafety and health, 3(1), 39-49.

Kamran S. Response analysis, challenges \& strategic vision for Pakistan amidst the COVID-19 crisis. Available at: Pakistan People's Party; 2020. https://en. baaghitv.com/wp-content/uploads/ 2020/07/PPP-Covid-19Paper.pdf

Lancet, T. (2020). India under COVID-19 lockdown. Lancet (London, England), 395(10233), 1315.

Legido-Quigley, H., Asgari, N., Teo, Y. Y., Leung, G. M., Oshitani, H., Fukuda, K., ... \& Heymann, D. (2020). Are high-performing health systems resilient against the COVID-19 epidemic?. The Lancet, 395(10227), 848850 .

Mangi, F. \& Devnath, A. (2020) Covid cases in South Asia are rising at the fastest rate in the world. Available at: https://theprint.in/health/covidcases-in-south-asia-are-rising-at-the-fastest-rate-in-the-world/438708/

Menon, S. (2020). Coronavirus in South Asia: is low testing hiding scale of the outbreak? BBC. Available at: https://www.bbc.com/news/world-asia-5342053

Mondeaux, C. (2020). South Asian countries ease coronavirus restrictions despite rising numbers. The Washington Diplomat. Available at: 2020. https://washdiplomat.com/south-asian-countries-ease-coronavirusrestrictions-despite-rising-numbers/

Nafees, M., \& Khan, F. (2020). Pakistan's Response to COVID-19 Pandemic and Efficacy of Quarantine and Partial Lockdown: A Review. Electron. J. Gen. Med, 17 (6) (2020), p. em240, 10.29333/ejgm/7951 1. 
Olsson, L., Jerneck, A., Thoren, H., Persson, J., \& O’Byrne, D. (2015). Why resilience is unappealing to social science: Theoretical and empirical investigations of the scientific use of resilience. Science advances, 1(4), e1400217.

OXFAM (2020). Press released entitled: 12,000 people per day could die from Covid-19 linked hunger by end of year, potentially more than the disease, warns Oxfam. Available at: https://www.oxfam.org/en/pressreleases/12000-people-day-could-die-covid-19-linked-hunger-end-year-potentially-more-disease

Perrings, C. (1998). Introduction: resilience and sustainability. Environment and Development Economics, 3(2), 221-262.

Poljanšek, K., Vernaccini, L., \& Marin Ferrer, M. (2020). INFORM Covid-19 Risk Index. Luxembourg:

Publications Office of the European Union. doi:10.2760/596184, JRC120799.

Roser, M. (2014). Human development index (HDI). Our World in Data.

Sagan, A., Thomas, S., McKee, M., Karanikolos, M., Azzopardi-Muscat, N., de la Mata, I., ... \& World Health Organization. (2020). COVID-19 and health systems resilience: lessons going forwards. Eurohealth, 26(2), 2024.

Samaranayake, N. (2020). Covid-19 and competition for influence in South Asia. Available at: https://www.nbr.org/publication/covid-19-and-competition-for-influence-in-south-asia/

Sarkar, A., Liu, G., Jin, Y., Xie, Z., \& Zheng, Z. J. (2020). Public health preparedness and responses to the coronavirus disease 2019 (COVID-19) pandemic in South Asia: a situation and policy analysis. Global Health Journal, 4(4), 121-132.

Sengupta, A., Zaidi, S., Sundararaman, T., Onta, S., \& Weerasinghe, M. (2019). Health in South Asia: Tackling the primary care access challenge in South Asia. Bmj, 363.

Shah, J., Karimzadeh, S., Al-Ahdal, T. M. A., Mousavi, S. H., Zahid, S. U., \& Huy, N. T. (2020). COVID-19: the current situation in Afghanistan. Lancet Glob Health, 8 (6), e771-e772.

Streatfield, P. K., \& Karar, Z. A. (2008). Population challenges for Bangladesh in the coming decades. Journal of health, population, and nutrition, 26(3), 261-272. https://www.ncbi.nlm.nih.gov/pmc/articles/PMC2740702 a

Shrestha, R., Shrestha, S., Khanal, P., \& KC, B. Nepal's first case of COVID-19 and public health response. $J$ Travel Med, 27 (3). taaa024, 10.1093/jtm/taaa02.

Sultana, R., Fuad, N., \& Ferdous, J. (2020). Containment Strategy during COVID-19 Outbreak-Analysis of Hospitals Hotspots in Dhaka to Prevent Community Transmission. Available at SSRN 3581666.

TI, S. K. (2020). Response Analysis, Challenges \& Strategic Vision for Pakistan Amidst the COVID-19 Crisis. On August, 21. Available at: Pakistan People's Party; 2020. https://en. baaghitv.com/wp-content/uploads/ 2020/07/PPP-Covid-19-Paper.pdf.

UNDP. (2020). Human Development Report. Available at: http://hdr.undp.org/en/composite/HDI

UNICEF. (2021). Situation Update: South Asia. UNICEF/UN0456981/Singh. Available at: Racing to Respond to the COVID-19 Crisis in South Asia.https://www.unicef.org/rosa/racing-respond-covid-19-crisis-south-asia

UNICEF. (2020). COVID-19 Situation Report No. 3. Available at:

https://reliefweb.int/report/afghanistan/unicef-regional-office-south-asia-covid-19-situation-report-no-3-march$\underline{18-24-2020}$

UNISDR, U. (2009). Global assessment report on disaster risk reduction: Risk and poverty in a changing climate (UN International Strategy for Disaster Reduction Secretariat, Geneva, 2009).

WHO Health Emergency Dashboard WHO (COVID-19) Homepage. available at: https://portal.who.int/report and https://Covid19. who.int/table

World Bank. (2021). Available at: the World Bank Blogs posted on April 06, 2021

World Bank (2011). Policy Research Paper on The Air Connectivity Index Measuring Integration in the Global Air Transport Network, prepared by Jean-François Arvis Ben Shepherd. The World Bank Poverty Reduction and Economic Management Network International Trade Department June 2011 WPS5722. 
M Aminul Islam / Why some Countries are more Resilient in South Asia to Confront COVID-19 Pandemic and Recovery?

Zhang, C., Jin, X., Chen, X., Leng, Q., \& Qiu, T. (2020). Antigenic evolution on global scale reveals potential natural selection of SARS-CoV-2 by pre-existing cross-reactive T cell immunity. bioRxiv.

\section{Appendix}

Table 1: Air Connectivity Index (2007) Source: Retrieved from Web at http://econ.worldbank. org. (Ref: JeanFrançois et al. 2011) Error! Bookmark not defined.

Table 2: Statistics related to Severity of Covid-19 in South Asian countries. Error! Bookmark not defined.

Table 3: Underlying factors for Resilience that assists in confronting Covid-19. Error! Bookmark not defined.

Table 4: Pre-pandemic country wise degree of vulnerability and level of Health Risk presented at $0-10$ scale where $0=$ more reliable $10=$ Less reliable)

Error! Bookmark not defined.

Figure 1: Comparison of health expenditure per capita (current US\$) amongst South Asian countries . .7

Figure 2: Cluster of Countries by Resilience level and Covid-19 Vulnerability and Risk . .8 